\title{
Bicuspid aortic valve
}

\section{(D)Dean Strinić', (D)Tea Friščićc ${ }^{*}$, (1) Jasna Čerkez Habek ${ }^{1,2}$ (1DJozica Šikić1,3}

'University Hospital "Sveti Duh", Zagreb, Croatia

${ }^{2}$ Croatian Catholic University, Zagreb, Croatia

${ }^{3}$ University of Zagreb, School of Medicine, Zagreb, Croatia
RECEIVED:

July 30, 2021

ACCEPTED:

August 5, 2021

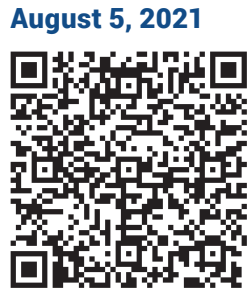

KEYWORDS: bicuspid aortic valve, congenital heart disease, valvulo-aortopathy

CITATION: Cardiol Croat. 2021;16(9-10):305. | https://doi.org/10.15836/ccar2021.305

*ADDRESS FOR CORRESPONDENCE: Tea Friščić, Klinička bolnica „Sveti Duh“, Sv. Duh 64, HR-10000 Zagreb, Croatia. / Phone: +385-91-3714-430 / E-mail: friscictea1@gmail.com

ORCID: Dean Strinić, https://orcid.org/0000-0001-6345-2037 • Tea Friščić, https://orcid.org/0000-0003-3189-8661 Jasna Čerkez Habek, https://orcid.org/0000-0003-3177-3797 • Jozica Šikić, https://orcid.org/0000-0003-4488-0559

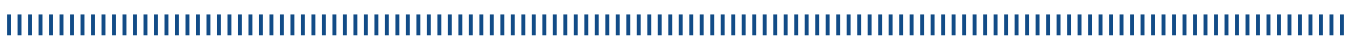

Bicuspid aortic valve (BAV) is the most common congenital heart disease with an estimated prevalence between $0.5 \%$ and $2 \%$. BAV is usually made of 2 unequal-sized leaflets where the larger leaflet has a central raphe or ridge that results from fusion of the commissures. Most common is the fusion of the right and left cusps which is associated with coarctation of the aorta. Pure BAV is rare, and it has symmetrical leaflets or there is no raphe ${ }^{2}$. The majority of BAV are an isolated birth defect, but there are also genetic causes. It can appear as a part of a syndrome (e.g., Shone's syndrome, Turner syndrome, Williams syndrome, Anderson syndrome), or because of a single gene mutation such as NOTCH1 and ACTA2, or a combination of multiple gene mutations. Recently, the role of the extracellular matrix role in the differentiation of the cells and formation of the leaflets is being investigated ${ }^{1,2}$. Because $20-84 \%$ of patients with a BAV develop ascending aortic dilatation, BAV should be regarded as a valvulo-aortopathy. The dissection incidence in BAV patients is eight times higher than in the general population ${ }^{3}$. The clinical presentation of patients with BAV varies from mild to severe valve disease and the symptoms typically develop in adulthood. The clinical manifestations depend on the function of the aortic valve, the aortopathy and acquired complications such as endocarditis. Infectious endocarditis affects 10-30\% of BAV patients during their lifetime and is more common in younger male patients ${ }^{1}$. Due to abnormal hemodynamics on the aortic wall and different activity of the matrix metalloproteinases, BAV is associated with dilatation in the aorta, especially the aortic root and ascending aorta, and coarctation of the aorta often occurs simultaneously. With the incidence between $59 \%$ and $81 \%$, aortic valve stenosis is the most common complication of the BAV, with calcification playing a major role ${ }^{1,2}$. Treatment strategies vary depending on the severity of the disease and dilation of the aorta. Together with valve replacement, transcatheter aortic valve implantation is now considered as an alternative option with good results ${ }^{1-3}$.
LITERATURE IIIIIIIIIIIIIIIIIIIIIIIIIIIIIIIIIIIIIIIIIIIIIIIIIIIIIIIIIIIIIIIIIIIIIIIIIIIIIIIIIIIIIIIIIIIIIIIIIIIIII

1. Sakellaropoulos S, Mohammed M, Svab S, Lekaditi D, Sakellaropoulos P, Mitsis A. Causes, Diagnosis, Risk Stratification and Treatment of Bicuspid Aortic Valve Disease: An Updated Review. Cardiol Res. 2020 Aug;11(4):205-212. https://doi.org/10.14740/cr1061

2. Siu SC, Silversides CK. Bicuspid aortic valve disease. J Am Coll Cardiol. 2010 Jun 22;55(25):2789-800. https://doi.org/10.1016/j.jacc.2009.12.068

3. Baumgartner H, De Backer J, Babu-Narayan SV, Budts W, Chessa M, Diller GP, et al; ESC Scientific Document Group. 2020 ESC Guidelines for the management of adult congenital heart disease. Eur Heart J. 2021 Feb 11;42(6):563-645. https://doi.org/10.1093/eurheartj/ehaa554
5. kongres Radne skupine za bolesti srčanih zalistaka Hrvatskoga kardiološkog društva s međunarodnim sudjelovanjem $5^{\text {th }}$ Congress of the Working Group on Valvular Diseases of the Croatian Cardiac Society with international participation September 2-4, 2021, Zagreb, Croatia
Cardiologia Croatica $\square$ 2021;16(9-10):305. 